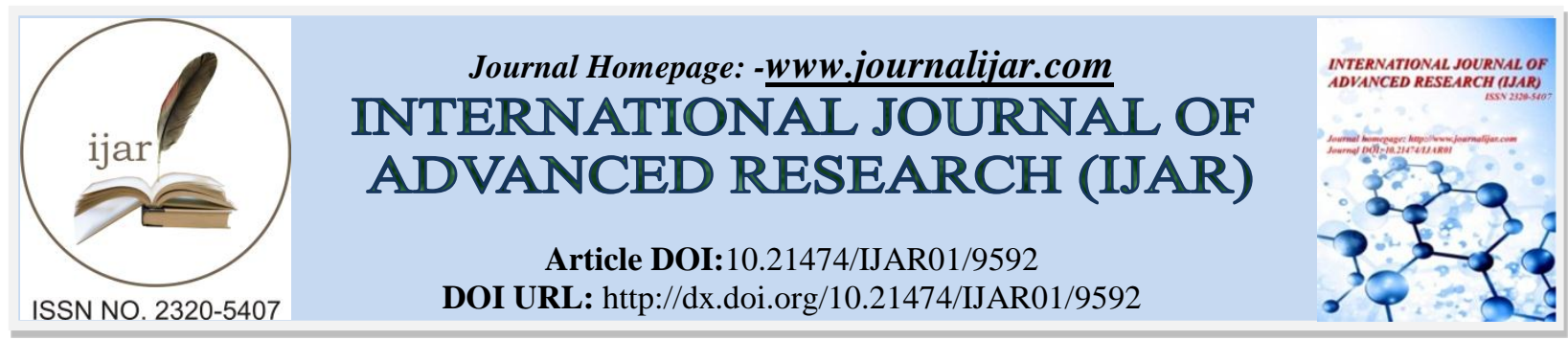

RESEARCH ARTICLE

\title{
WATER HYACINTH (EICHHORNIA CRASSIPES) AS A PROMISING BIOSORBENT IN REMOVAL OF HEAVY METALS.
}

Farah Monowara Jahangiri.

Department of Soil, Water and Environment, University of Dhaka, Dhaka, Bangladesh.

\section{Manuscript Info}

Manuscript History

Received: 18 June 2019

Final Accepted: 20 July 2019

Published: August 2019

Keywords

Eichhornia crassipes, heavy metals removal, biosorption, pyrolysis, biochar.

\begin{abstract}
Water hyacinth (Eichhornia crassipes) is a naturally abundant plant having substantial heavy metal adsorptive capacity. E. crassipes is considered to be a noxious weed in many parts of the world due to its proficiency to grow and depletion of nutrients and oxygen from water bodies. Nonetheless, several studies have shown E. crassipes as a candidate for the treatment of wastewater contaminated with heavy metals. The present review aims to compile in a single paper the numerous studies conducted on the use of water hyacinth species for the removal of heavy metals in solution. The methods include a binder material produced either from the roots, shoots, fibers, pellets, the whole biomass, biochar or activated carbon derived from the water hyacinth biomass, and involve a process of binding such as biosorption, pyrolysis, immobilization with micro algae, or modification with nanoparticles. The paper also specifies with each method the extent of removal of metal ions and discusses about a specific disposal method of the metal contaminated biomass. Regardless the ability to act as an invasive aquatic species, E. crassipes has a great potential to be used as an in situ cost effective biosorbent phytotechnology for the amelioration of contaminated wastewaters with heavy metals.
\end{abstract}

Copy right, IJAR, 2019. All rights reserved.

\section{Introduction:}

Increasing industrial activities had caused a concomitant increase in the use of heavy metals over the last few decades (Reddy et al., 2012). Consequently, water bodies are the main preferences for the ultimate and final disposal of these industrial effluents causing its serious pollution. Moreover, this specifies to an alarming risk to global environment owing to the persistence, abundance and significant toxicity of these metals (Ahmed et al., 2015a; Ahmed et al., 2015b; Islam et al., 2015). Therefore, it is necessary to treat metal-contaminated wastewater prior to its discharge to the environment.

The most commonly applied physical and chemical treatment methods for heavy metal removal are chemical precipitation as hydroxides, carbonates or sulfides and subsequent liquid-solids separation by gravity settling, and flotation or filtration; sorption (adsorption, ion exchange); membrane processes; electrolytic recovery and liquidliquid extraction. However, beside the merits, each method has been limited in its application due to some significant disadvantages, for instance, incomplete removal, high-energy requirements, production of toxic sludge or

Corresponding Author: Farah Monowara Jahangiri.

Address: Department of Soil, Water and Environment, University of Dhaka, Dhaka, Bangladesh. 
waste products that also require disposal and become economically unviable for the removal of heavy metals at lower concentrations (Wang and Chen, 2009).

The adsorption process is arguably one of the most popular methods for the removal of heavy-metal ions because of its simplicity, convenience, and high removal efficiency (Afkhami et al., 2007). In common sorption processes, commercial activated carbon and synthetic resins are usually used to gain high removal efficiency. However, due to their high production cost these two sorbents have not gained widespread use and popularity. There is a need for effective, cost-efficient and environment-friendly technology for the removal of heavy metal (Zheng et al., 2009).

Phytoremediation is such a remediation technique which can be used for the effective removal of heavy metals from the large polluted site where other chemical and physical remediation technologies prove to be not applicable and costly (Garbisu and Alkorta, 2003). Aquatic macrophytes have greater potential to accumulate heavy metals present inside their plant bodies (Priya and Selvan, 2014). In view of this, considerable attention has been focused on the development of adsorbents from various types of aquatic plants as these are inexpensive and locally available (Munagapati et al., 2010). The basic component of these low-cost organic biomass includes cellulose, lignin, hemicellulose, extractives, lipids, proteins, simple sugars, starch, etc. containing variety of functional groups that facilitates metal complexation and helps for the sequestration of heavy metals (Hashem et al., 2005; Hashem et al., 2007).

Water hyacinth (Eichhornia crassipes) (Family: Pontederiaceae) is a free-floating perennial aquatic plant originated from tropical and subtropical South America and is now widespread in all tropical climates. It is ranked as one of worst invasive weed globally (Bhattacharya et al. 2015; Villamagna and Murphy 2016). The genus Eichhornia comprises seven species of water hyacinth among which E. crassipes is the most dominant regarding distribution and have been reported to produce biomass faster than the other E. sp. (Rahman and Hasegawa 2011). Owing to its superior tolerance to a contaminated environment, rapid growth (Zhang et al., 2014) and high economic value with diverse potential applications (Rezania et al., 2015a), water hyacinth has gained widespread interest in environmental phytoremediation applications (Rezania et al., 2015b).

Water hyacinth shows high removal rates for manganese $(\mathrm{Mn})$, iron $(\mathrm{Fe})$, cadmium $(\mathrm{Cd})$, zinc $(\mathrm{Zn})$, copper $(\mathrm{Cu})$, chromium (Cr), nickel (Ni), arsenic (As) and mercury (Hg) (Mokhtar et al., 2011) from wastewater solutions along with absorbing organic substances such as formaldehyde, phenol, oxalic, acetic and formic acid. Water hyacinth is the best plant species for the accumulation of Cd (Liao and Chang, 2004). Leaf tissues of water hyacinth show great accumulation ability for the mercury, harvesting of such plant species could help to remove the mercury contamination (Wang et al. 2002). Kumar et al. (2016) reported that water hyacinth is the best candidate as compared to other aquatic plants for the phytoremediation of pulp and paper mill effluents load with different heavy metals $\mathrm{Cr}, \mathrm{Cu}, \mathrm{Mn}, \mathrm{Cd}, \mathrm{Pb}, \mathrm{Fe}, \mathrm{Zn}, \mathrm{Ni}$, and organic load EC (electrical conductivity), TDS, COD, BOD, TKN (total Kjeldahl nitrogen). Liao and Cheng (2004) ranked the heavy metal removal rate based on the ability of water hyacinth to remove $(\mathrm{Cu}>\mathrm{Zn}>\mathrm{Ni}>\mathrm{Pb}>\mathrm{Cd})$ and showed that higher and lower removal efficiency belonged to $\mathrm{Cu}$ and Cd, respectively. Xiaomei et al. (2004) used water hyacinth for the removal of $\mathrm{Zn}$ and Cd from wastewater and also measured the concentration of $\mathrm{Cd}$ and $\mathrm{Zn}$ absorbed in different parts of water hyacinth (stem, leaves, roots, flowers). It was observed for the presence of $2040 \mathrm{mg} / \mathrm{kg}$ of Cd and $9650 \mathrm{mg} / \mathrm{kg}$ of $\mathrm{Zn}$ accumulated in the roots of water hyacinth. According to Shaban et al. (2005) to treat one liter of wastewater contaminated with $1500 \mathrm{mg} / \mathrm{L}$ arsenic requires $30 \mathrm{~g}$ of dried water hyacinth root for a period of 24 hours. Emerhi (2011) estimated chromium (III) removal from the aqueous solution and found the removal rate to be $87.52 \%$ with $10 \mathrm{mg} \mathrm{Cr} / 1 \mathrm{solution}$. The objective of this review was to assemble the different usage methods of water hyacinth as a biosorbent in removal of heavy metals from aquatic systems.

\section{Methods:}

Literature search was conducted by searching for scholarly articles in PubMed, Google scholar, and Scopus by using search term "heavy metal removal", "techniques of heavy metal removal", "water hyacinth", "Eichhornia crassipes", "water hyacinth as a biosorbent", "Lead removal + water hyacinth", "Cadmium removal+water hyacinth", "Chromium removal+water hyacinth". Further searches were done after finding the relevant articles and references therein. 


\section{Results:}

Based on the literature search, the methods through which water hyacinth plant is used as a biosorbent in heavy metal removal could be divided into eight groups. These are presented here in this result section.

\section{Floating Bed Technique:}

In this method done by Abbas et al. (2019), the effectiveness of water hyacinth was tested for the phytoremediation of landfill leachate for a period of 15 days. Fifteen plastic containers were used in experimental setup where aquatic plants were fitted as a floating bed with the help of thermo-pole sheet. It was observed that both plants significantly $(\mathrm{p}<0.05 / \mathrm{p}<0.01 / \mathrm{p}<0.001)$ reduce the physicochemical parameters $\mathrm{pH}$, TDS, BOD, COD and heavy metals like $\mathrm{Zn}, \mathrm{Pb}, \mathrm{Fe}, \mathrm{Cu}$ and $\mathrm{Ni}$ from landfill leachate. Maximum reduction in these parameters was obtained at $50 \%$ and $75 \%$ landfill leachate treatment and their removal rate gradually increased from day 3 to day 15 of the experiment. The maximum removal rate for heavy metals was for $\mathrm{Zn}(80-90 \%)$, $\mathrm{Fe}(83-87 \%)$ and $\mathrm{Pb}(76-84 \%)$. Value of bioconcentration and translocation factor was less than 1 which indicates the low transport of heavy metals from roots to the above-ground parts of the plant. Besides, water hyacinth accumulates these heavy metals inside its body without showing much reduction in growth and showing tolerance to all the present metals.

Another comprehensive study on arsenic removal from water by E. crassipes was performed by Alvarado et al. (2008), and the results showed that it had a removal rate of $600 \mathrm{mg}$ arsenic $\mathrm{ha}^{-1} \mathrm{~d}^{-1}$ under field conditions and a removal recovery of $18 \%$ under laboratory conditions. The removal efficiency of water hyacinth was higher due to its high biomass production and favorable climatic conditions. Mishra et al. (2008) compared arsenic removal efficiency of E. crassipes, L. minor and S. polyrhiza from tropical opencast coal mine effluent and observed that $E$. crassipes had the highest removal efficiency (80\%) compared to other aquatic macrophytes over a $25 \mathrm{~d}$ course. This was supposed to be due to faster growth rate (Muramoto and Oki, 1983; Kelley et al., 1999), greater biomass production, and higher uptake ability of arsenic. Therefore, the results obtained from both studies suggest that Eichhornia crassipes is a suitable candidate for the removal of pollution load from landfill leachate.

\section{Vertical Surface Flow Constructed Wetlands:}

A study was led by Agarry et al. (2018) to evaluate the potential of a vertical surface flow constructed wetland (VSF-CW) vegetated with Eichhornia crassipes in treating petroleum refinery secondary wastewater under tropical conditions. Also, to provide a comparative evaluation of biotreatment kinetic models (traditional first order and other alternative kinetic models) proposed to describe the removal kinetics of organics (biochemical oxygen demand (BOD) and chemical oxygen demand (COD)), nitrate-nitrogen and total petroleum hydrocarbons (TPH) in wetland systems. The refinery secondary wastewater was characterized and treated in five VSF-CWs. Eichhornia crassipes were planted in three VSF-CWs and the remaining two VSF-CWs served as the unvegetated control. The wastewater relatively had high levels of turbidity $(18.30 \pm 3.88 \mathrm{NTU})$, BOD $(20.40 \pm 2.20 \mathrm{mg} / \mathrm{L})$, COD $(86 \pm 6.0$ $\mathrm{mg} / \mathrm{L})$, TPH $(16.6 \pm 1.76 \mathrm{mg} / \mathrm{L})$, oil and grease $(18.4 \pm 2.00 \mathrm{mg} / \mathrm{L})$, heavy metals $($ Cadmium $(0.034 \pm 0.01 \mathrm{mg} / \mathrm{L})$, Lead $(0.12 \pm 0.05 \mathrm{mg} / \mathrm{L})$, Chromium $(0.47 \pm 0.01 \mathrm{mg} / \mathrm{L})$, Iron $(1.54 \pm 0.25 \mathrm{mg} / \mathrm{L})$ and Nickel $(0.09 \pm 0.01 \mathrm{mg} / \mathrm{L}))$ and Chloride $(1412 \pm 9.6 \mathrm{mg} / \mathrm{L})$. The vegetated VSF-CWs significantly performed better than the unvegetated control and resulted in the removal efficiencies of $91.5 \%$ turbidity, 94.6\% BOD5, 80.2\% COD, 92.6\% TPH, 90.4\% oil and grease, 94\% cadmium, 92.5\% lead, 93\% chromium, 94.8\% iron, 92.2\% nickel, and $57.7 \%$ chloride. Thus, Eichhornia crassipes planted VSF-CW has the potential of treating refinery secondary wastewater to discharge permissible limits.

\section{Using Dried powder of root and shoot:}

Dried water hyacinth as biosorbent for metal ions were also investigated in many literatures by powder of its roots and shoots. The chemical analysis and FTIR shows that water hyacinth is a mixture of cellulose and lignin (Ibrahim et al., 2012). Dried shoot and root were found as good sorbent for removal of more than $75 \%$ for $\mathrm{Cd}$ and more than $90 \%$ for $\mathrm{Pb}$ at optimum dosage of $5.0 \mathrm{~g} / \mathrm{l}, \mathrm{pH} 5.0$; equilibrium time within 30-60 min by Ibrahim et al. (2012) where the removal using root and shoot were nearly equal. Besides, using dried roots at optimum dosage of $2.0 \mathrm{~g} / \mathrm{l}, \mathrm{pH} 5.0$; equilibrium time within $90 \mathrm{~min}$, Jahangiri et al. (2018) obtained a removal of $92 \% \mathrm{~Pb}$ (II) and $54 \% \mathrm{Cd}(\mathrm{II})$. In both the cases, second-order kinetics was the applicable model.

The mechanisms for this sorption by the WMass should be related firstly to abundant functional groups ( $-\mathrm{OH},-\mathrm{NH}$, $\mathrm{C}-\mathrm{O}, \mathrm{C}-\mathrm{N}$ and $\mathrm{CO}$ ) on the biomass surface that could bind metal ions through complexation (Abdolali et al., 2016, $\mathrm{Li}$ and $\mathrm{Yu}, 2014)$, as shown as the strong bands at $3415 \mathrm{~cm}-1(-\mathrm{OH}$ or $-\mathrm{NH}), 1640 \mathrm{~cm}-1(\mathrm{CO}), 1319 \mathrm{~cm}-1(\mathrm{C}-\mathrm{N})$ and $1055 \mathrm{~cm}-1(\mathrm{C}-\mathrm{O})$ observed in the IR spectrum of the WMass. Secondly, the SEM-EDX analysis indicated that 
some metal elements ( $\mathrm{K}$ and $\mathrm{Mg}$ ) inherently existed in the WMass was eliminated after sorption of metal ions, suggesting the replacement of $\mathrm{K}$ and $\mathrm{Mg}$ elements by metal ions through cation exchange, which played an important role for sorption of heavy metals by many mineral-containing biosorbents (Yuvaraja et al., 2014).

Schneider et al. (1995) also studied the feasibility of dried water hyacinth roots for the removal of $\mathrm{Pb}^{2+}, \mathrm{Cu}^{2+}, \mathrm{Cd}^{2+}$ and $\mathrm{Zn}^{2+}$ ions from aqueous solution. The authors found that the dried roots and aerial parts of the water hyacinth are better biosorbents than the biomass of the bacterium Mycobacterium phlei, the yeast Candida parapsilosis, fungal Rhizopus oryzae strains, and acacia bark in terms of lead and copper uptake per dried mass of biosorbent.

\section{As Fibre}

A study was led by Buasri et al. (2012) in which fibres from water hyacinth were used to remove $\mathrm{Cu}$ (II) and $\mathrm{Zn}$ (II) ions from aqueous solutions. The fibres were prepared through reaction of cellulose with phosphoric acid according to the method described by Suflet et al. (2006). In a $500 \mathrm{~mL}$, three-necked flask equipped with a nitrogen inlet, a condenser, a thermometer, and a stirrer, $224 \mathrm{~g}$ urea was added, heated at $140^{\circ} \mathrm{C}$ and flushed with nitrogen. Water hyacinth $(30 \mathrm{~g})$ and $168 \mathrm{~mL}$ phosphorous acid were added alternatively portionwise to the molten urea in order to reduce the foaming. The reaction was allowed to proceed at $150^{\circ} \mathrm{C}$ for $2 \mathrm{~h}$. The fiber was washed with distilled water and acetone. A sample of fiber was treated with $0.5 \mathrm{M}$ hydrochloric acid for $24 \mathrm{~h}$ under slow stirring. The modified cellulose was washed several times with deionized water to remove excess acid from biosorbent. It was dried for $24 \mathrm{~h}$ at $60^{\circ} \mathrm{C}$ in an oven. Biosorption experiments where then carried out with prepared biosorbent and metal solutions of $\mathrm{Cu}\left(\mathrm{NO}_{3}\right)_{2}$ and $\mathrm{Zn}\left(\mathrm{NO}_{3}\right)_{2}$. The equilibrium biosorption isotherms showed that water hyacinth possess high affinity and sorption capacity for $\mathrm{Cu}$ (II) and $\mathrm{Zn}$ (II) ions, with sorption capacities of $99.42 \mathrm{mg} \mathrm{Cu}^{2+}$ and $83.01 \mathrm{mg} \mathrm{Z \textrm {n } ^ { 2 + }}$ per gram biomass, respectively. All results showed that water hyacinth fiber is an alternative low cost biosorbent for removal of heavy metal ions from aqueous media.

\section{Preparing Biochar by Pyrolysis}

Biochar derived from biomass, especially from waste biomass, is recognized as one of the most available adsorbents due to their specific properties such as large surface area, highly porous structure and enriched surface functional groups (Lonappan et al., 2016). Several literatures have reported the conversion of water hyacinth into biochar followed by application in the treatment of wastewater (Zhang et al., 2015, 2016; Xu et al., 2016).

A study was led by Li et al. (2018) in which biochars were produced from long-root Eichhornia crassipes at four temperatures: $200,300,400$ and $500^{\circ} \mathrm{C}$, referred to as LEC200, LEC300, LEC400 and LEC500, respectively. The sorption ability of lead, zinc, copper and cadmium from aqueous solutions by four kinds of biochars was investigated. All the biochars had lower values of CEC and higher values of pH. LEC500 was the best one to bind toxic metals which can be reflected in the results of SEM, BET and elemental analyser. It was also found that alkyl, carboxyl, phosphate and cyano groups in the biochars can play a role in binding metals. In addition, the sorption processes of four metals by the biochars in different metal concentration $\mathrm{R}^{2}>0.95$ were all excellently represented by the pseudo-second-order model with all correlation coefficients. It could also be described satisfactorily by the Langmuir isotherms. According to calculated results by the Langmuir equation, the maximum removal capacities of $\mathrm{Pb}(\mathrm{II}), \mathrm{Zn}(\mathrm{II}), \mathrm{Cu}(\mathrm{II})$ and $\mathrm{Cd}(\mathrm{II})$ at $298 \mathrm{~K}$ were $39.09 \mathrm{mg} \mathrm{g}^{-1}, 45.40 \mathrm{mg} \mathrm{g}^{-1}, 48.20 \mathrm{mg} \mathrm{g}^{-1}$ and $44.04 \mathrm{mg} \mathrm{g}^{-1}$, respectively. The positive value of $\Delta \mathrm{H}_{0}$ confirmed the adsorption process was endothermic and the negative value of $\Delta \mathrm{G}_{0}$ confirmed the adsorption process was spontaneous. The sorption capacities were compared with several other lignocellulosic materials which implied the potential of long-root Eichhornia crassipes waste as an economic and excellent biosorbent for eliminating metal ions from contaminated waters.

Furthermore, to enhance the adsorption capacity of biochar, literatures have shown the following chemical or physical modification of biochar:

\section{$\mathrm{Fe}_{3} \mathrm{O}_{4}$ modified biochar:}

Zhang et al. (2016). prepared magnetite-modified water hyacinth biochar for arsenate removal and found that $100 \%$ $\mathrm{As}(\mathrm{V})$ was depleted by magnetite-modified biochar compared to $8.9 \%$ by no Fe-modified biochar.

\section{Modification with nanoparticles:}

The adsorbing material relating to zinc nanostructures have also aroused increasing interest. CuO-ZnO composite nanofibers (Malwal and Gopinath, 2017), ZnO microspheres (Lei et al., 2017), Al-doped ZnO rods (Chouchene et al., 2017) and $\mathrm{ZnO}$ nanorods (Ansari et al., 2016) exhibited excellent adsorption capacity. In particular, ZnO loaded 
on activated carbon and $\mathrm{ZnO}$ thin films showed effective adsorption for $\mathrm{Pb}$ (II) (Kikuchi et al., 2006) and $\mathrm{Cu}$ (II) (Bagheri et al., 2014) removal, respectively. These researches suggest it may be feasible to load ZnO nanoparticles on water hyacinth biochar for efficient $\mathrm{Cr}(\mathrm{VI})$ removal.

In a study by $\mathrm{Yu}$ et al. (2018), biochar derived from waste water hyacinth was prepared and modified by $\mathrm{ZnO}$ nanoparticles for $\mathrm{Cr}(\mathrm{VI})$ removal from aqueous solution with the aim of $\mathrm{Cr}(\mathrm{VI})$ removal and management of waste biomass. The effect of carbonization temperature $\left(500-800{ }^{\circ} \mathrm{C}\right), \mathrm{ZnO}$ content $(10-50 \mathrm{wt} \%)$ loaded on biochar and contact time $(0.17-14 \mathrm{~h})$ on the $\mathrm{Cr}(\mathrm{VI})$ removal were investigated. It was found that higher than $95 \%$ removal efficiency of $\mathrm{Cr}(\mathrm{VI})$ can be achieved with the biochar loaded $30 \mathrm{wt} \% \mathrm{ZnO}$. The adsorption kinetics of the sorbent is consistent with the pseudo-second-order kinetic model and adsorption isotherm follows the Langmuir model with maximum adsorption capacity of $43.48 \mathrm{mg} \mathrm{g}^{-1}$ for $\mathrm{Cr}(\mathrm{VI})$. Multiple techniques such as XRD, XPS, SEM, EDX and FT-IR were performed to investigate the possible mechanisms involved in the $\mathrm{Cr}$ (VI) adsorption. The results show that there is precipitation between chromium ions and $\mathrm{Zn}$ oxide. Furthermore, the $\mathrm{ZnO}$ nanoparticles acts as photocatalyst to generate photo-generated electrons to enhance the reduction of $\mathrm{Cr}(\mathrm{VI})$ to $\mathrm{Cr}$ (III). The as-prepared $\mathrm{ZnO} / \mathrm{BC}$ possess good recyclability and the removal ratio remained at about $70 \%$ in the fifth cycle, which suggests that both contaminants removal and effective management of water hyacinth can be achieved by the approach.

\section{Using Eichhornia crassipes-derived Activated Carbon (AEC)}

Activated carbon was prepared by Kadirvelu et al. (2004) from Eichhornia crassipes by cutting the plant material into small pieces, dried in sunlight until the moisture had partially evaporated and then further dried in a hot air oven for $24 \mathrm{~h}$ at $60^{\circ} \mathrm{C}$. The completely dry material was packed into an iron vessel and covered with a tight-fitting lid to avoid contact with atmospheric air except for that entrapped within the voids in the material being activated. This arrangement was placed in a muffle furnace and heated at a temperature of $500^{\circ} \mathrm{C}$ for $1 \mathrm{~h}$. After cooling, the resulting product was removed, ground and passed through 125-180 $\mu \mathrm{m}$ sieve. At last, batch sorption experiments were run with the AEC and aqueous solution as well as synthetic wastewaters to study its capability in $\mathrm{Hg}(\mathrm{II})$ removal.

In the batch sorption experiments with aqueous solutions, the contact time fixed at $6 \mathrm{~h}$ ensured that equilibrium had been attained. The equilibrium time for carbonized waste newsprint fibre whereas was $16 \mathrm{~h} \mathrm{for} 100 \mathrm{mg} / \mathrm{l} \mathrm{Hg}$ (II). This indicates that AEC required a lesser contact time for the complete elimination of $\mathrm{Hg}$ (II) from solution compared to activated carbon derived from newsprint fibre and commercial activated carbon (CAC) (Namasivayam and Periasamy, 1993; Aoyama et al., 2000). Besides, an adsorbent dosage of $1.6 \mathrm{~g} / \mathrm{l}$ carbon was required to effect the quantitative removal of $\mathrm{Hg}$ (II) from $1000 \mathrm{ml}$ of both $20 \mathrm{mg} / \mathrm{l}$ and $40 \mathrm{mg} / \mathrm{l} \mathrm{Hg}$ (II) solutions. Pulido et al. (1998) found that $5 \mathrm{~g} / \mathrm{l} \mathrm{CAC}$ was required to effect the same removal of $\mathrm{Hg}$ (II), i.e. ca. three-times greater than that observed with our carbon. This demonstrates the higher efficiency of AEC relative to CAC. The optimum pH was found to be 5 .

It was then applied to synthetic wastewaters which were prepared using literature methods by Kadirvelu (1998), adjusted at different $\mathrm{pH}$ values and agitated with $50 \mathrm{mg}$ carbon for $6 \mathrm{~h}$. The removal of $\mathrm{Hg}$ (II) from synthetic wastewater was dependent upon the composition, nature and the $\mathrm{pH}$ of the system. Increasing the carbon content led to an increase in the percentage removal of $\mathrm{Hg}$ (II) and the minimum dosage of carbon required for the removal of $\mathrm{Hg}$ (II) was $200 \mathrm{mg} / 50 \mathrm{ml}$ solution. The percentage removal of $\mathrm{Hg}$ (II) also increased with increasing $\mathrm{pH}$ and attained a maximum value of $73 \%$ at a $\mathrm{pH}$ value of 5 . The experiments conducted on the removal of $\mathrm{Hg}$ (II) from synthetic wastewater confirmed the validity of the results obtained from the batch mode studies, i.e. AEC can be used effectively for the removal of $\mathrm{Hg}(\mathrm{II})$ from synthetic wastewater.

Immobilizing microalgal cells on water hyacinth derived pellets:

In this experiment done by Shen et al. (2018), a complex of water-hyacinth derived pellets immobilized with Chlorella sp. was applied, for the first time, in the bioremediation of Cadmium (Cd). The Cd(II) removal efficiency of the complex was optimized by investigating several parameters, including the pellet materials, algal culture age, and light intensity. Results showed that the $\mathrm{Cd}(\mathrm{II})$ removal efficiency was positively related to the algal immobilization efficiency and the algal bioaccumulation capacity. Since higher surface hydrophilicity leads to higher immobilization efficiency, the water hyacinth leaf biochar pellet (WLBp) was selected as the optimal carrier. A maximum Cd(II) removal efficiency of $92.45 \%$ was obtained by the complex of WLBp immobilized with algal cells in stationary growth phase and illuminated with a light intensity of $119 \mu \mathrm{molm}^{-2} \mathrm{~s}^{-1}$. Recovery tests on both 
microalgal cells and the WLBp demonstrated that the algal cells and the biochar pellet can be economically recycled and reused.

\section{Disposal of Water Hyacinth Biomass Contaminated by Biosorption of Heavy Metals}

Heavy metals accumulated in biomass may be released back to the environment if they were not properly disposed of, because most biomass are readily degradable. Pyrolysis can transform biomass into stable biochars that could be applied as a soil amendment, and such a transformation is also considered a promising strategy for carbon sequestration (Mao et al., 2012). For the purpose of safe disposal of biomass contaminated by biosorption of heavy metals, phosphate assisted pyrolysis of water hyacinth biomass contaminated by lead $(\mathrm{Pb})$ was tried by Shi et al. (2017) to reduce the bioavailability and leaching potential of $\mathrm{Pb}$, using direct pyrolysis without additive as a control method. Direct pyrolysis of the contaminated biomass at low temperatures $\left(300\right.$ and $\left.400{ }^{\circ} \mathrm{C}\right)$ could reduce the bioavailability of $\mathrm{Pb}$, but the leaching potential of $\mathrm{Pb}$ was increased with the rising pyrolysis temperature. While phosphate-assisted pyrolysis significantly enhanced the recovery and stability of $\mathrm{Pb}$ in the char. Specifically, the percentages of bioavailable $\mathrm{Pb}$ and leachable $\mathrm{Pb}$ in the chars obtained by phosphate assisted pyrolysis at low temperatures were reduced to less than $5 \%$ and $7 \%$, respectively. The sequential extraction test indicated the transformation of $\mathrm{Pb}$ into more stable fractions after phosphate-assisted pyrolysis, which was related to the formation of $\mathrm{Pb}$ phosphate minerals including pyromorphite and lead-substituted hydroxyapatite.

\section{Conclusion:}

This paper has discussed the different possibilities of using water hyacinth for the removal of heavy metals. It has also been evident that among the aquatic plants, water hyacinth has got more heavy metals uptake capability and improving the water quality. As heavy metals are up taken by the roots of the plant, concentrated in them, or translocated and concentrated to the shoots and other plant tissues, harvesting the plant can permanently remove the contaminants. Moreover, in terms of expense, it is also cheaper than different advanced technologies which needs more cost to work for the evacuation of pollutants from the wastewater. There are also possible scopes for recovery of valuable heavy metals from the plants by burning and extracting the metals from the ash. Thus, with the advanced use of phytotechnology, water hyacinth can be a viable tool for bioremediation.

\section{References:}

1. Abbas, Z., Arooj, F., Ali, S., Zaheer, I.E., Rizwan, M. and Riaz, M.A. (2019): Phytoremediation of landfill leachate waste contaminants through floating bed technique using water hyacinth and water lettuce. Int. J. Phytoremediation, 31:1-12.

2. Abdolali, A., Ngo, H.H., Guo, W., Lu, S., Chen, S.S., Nguyen, C.N., Zhang, X., Wang, J. and Wu, Y. (2016): Breakthrough biosorbent in removing heavy metals: equilibrium, kinetic, thermodynamic and mechanism analyses in a lab-scale study. Sci. Total Environ., 542:603-611.

3. Afkhami, A., Madrakian, T., Amini, A. and Karimi, Z. (2007): Effect of treatment of carbon cloth with sodium hydroxide solution on its adsorption capacity for the adsorption of some cations. Colloids Surf A Physicochem. Eng. Aspects, 304:36-40.

4. Ahmed, M.K., Baki, M.A., Islam, M.S., Kundu, G.K., Sarkar, S.K. and Hossain, M.M. (2015a): Human health risk assessment of heavy metals in tropical fish and shell fish collected from the river Buriganga, Bangladesh. Environ. Sci. Pollut. Res., 22:15880.

5. Ahmed, M.K., Shaheen, N., Islam, M.S., Al-Mamun, M.H., Islam, S. and Banu, C.P. (2015b): Trace elements in two staple cereals (rice and wheat) and associated health risk implications in Bangladesh. Environ. Monit. Assess., 187: 326-336.

6. Alvarado, S., Guédez, M., Lué-Merú, M.P., Nelson, G., Alvaro, A., Jesús, A.C. and Gyula, Z. (2008): Arsenic removal from waters by bioremediation with the aquatic plants water hyacinth (Eichhornia crassipes) and lesser duckweed (Lemna minor). Bioresour. Technol., 99: 8436-8440.

7. Aoyama, M., Seki, K., Kasai, A., Kurimoto, Y., Chen, K. and Doi, S. (2000) Environ. Technol. 21

8. Bhattacharya, A., Haldar, S. and Chatterjee, P.K. (2015): Geographical distribution and physiology of water hyacinth (Eichhornia crassipses) the invasive hydrophyte and a biomass for producing xylitol. Int. J. Chem. Tech. Res., 7: 1849-1861.

9. Buasri, A., Chaiyut, N., Tapang, K., Jaroensin, S. and Panphrom S. (2012): Biosorption of Heavy Metals from Aqueous Solutions Using Water Hyacinth as a Low Cost Biosorbent. Civil and Environmental Research, 2(2): $17-24$. 
10. Emerhi, E.A. (2011): Physical and combustion properties of briquettes produced from sawdust of three hardwood species and different organic binders. Adv. Appl. Sci. Res., 2: 236-246.

11. Garbisu, C. and Alkorta, I. (2003): Basic concepts on heavy metal soil bioremediation. Eur. J. Min. Proc. Environ. Protect., 3(1): 5866.

12. Hashem, A., Abdel-Halim, E.S., El-Tahlawy, K.F. and Hebeish, A. (2005): Enhancement of the adsorption of $\mathrm{Co}(\mathrm{II})$ and $\mathrm{Ni}(\mathrm{II})$ ions onto peanut hulls through esterification using citric acid. Adsorption Science \& Technology, 23: 367-380.

13. Hashem, A., Akasha, R.A., Ghith, A. and Hussein, D.A. (2007): Adsorbent based on agricultural wastes for heavy metal and dye removal: A review. Energy Education Science and Technology, 19: 69-86.

14. Islam, M.S., Ahmed, M.K., Habibullah-Al-Mamun, M. and Hoque, M.F. (2015): Preliminary assessment of heavy metal contamination in surface sediments from a river in Bangladesh. Environ Earth Sci., 73(4): 18371848.

15. Jahangiri, F.M., Hoque, S. and Hossain, M.E. (2018): Water Hyacinth Roots for Removal of Aqueous Lead and Cadmium: Possible Applications in Wastewaters. Lambert Academic Publishing, Germany, ISBN: 978-613-989584-7.

16. Kadirvelu, K. (1998): PhD thesis, Bharathiar University, Coimbatore, India.

17. Kadirvelu, K., Kanmani, P., Senthilkumar, P. and Subburam, V. (2004): Separation of Mercury(II) from Aqueous Solution by Adsorption onto an Activated Carbon Prepared from Eichhornia crassipes. Adsorption Science \& Technology, 22(3): 207-222.

18. Kelley, C., Mielke, R.E., Dimaquibo, D., Curtis, A.J. and DeWitt, J.G. (1999): Adsorption of Eu(III) onto roots of water hyacinth. Environ. Sci. Technol., 33: 1439-1443.

19. Kumar, V., Chopra, A.K., Singha, J., Thakura, R.K., Srivastava, S. and Chauhan, R.K. (2016): Comparative assessment of phytoremediation feasibility of water caltrop (Trapa natans L.) and water hyacinth (Eichhornia crassipes Solms.) using pulp and paper mill effluent. Arch. Agric. Environ. Sci., 1(1): 13-21.

20. Li, Q., Tang, L., Hu, J., Jiang, M., Shi, X., Zhang, T., Li, Y. and Pan, X. (2018): Removal of toxic metals from aqueous solution by biochars derived from long-root Eichhornia crassipes. R. Soc. open sci. 5: 180966.

21. Li, W.W. and Yu, H.Q. (2014): Insight into the roles of microbial extracellular polymer substances in metal biosorption. Bioresour. Technol., 160: 15-23.

22. Liao, S. and Chang, W. (2004): Heavy metal phytoremediation by water hyacinth at constructed wetlands in Taiwan. Photogramm. Eng. Remote. Sens., 54: 177-185.

23. Liao, S.W. and Chang, W.L. (2004): Heavy metal phytoremediation by water hyacinth at constructed wetlands in Taiwan. J. Aquat. Plant Manage., 42:60-68.

24. Lonappan, L., Rouissi, T., Das, R.K., Brar, S.K., Ramirez, A.A., Verma, M., Surampalli, R.Y. and Valero, J.R. (2016): Adsorption of methylene blue on biochar microparticles derived from different waste materials. Waste Manag., 49: 537-544.

25. Mao, J.D., Johnson, R.L., Lehmann, J., Olk, D.C., Neves, E.G., Thompson, M.L. and Schmidt-Rohr K. (2012): Abundant and stable char residues in soils: implications for soil fertility and carbon sequestration Environ. Sci. Technol., 46: 9571-9576.

26. Mishra, V., Upadhyay, A., Pathak, V. and Tripathi, B. (2008): Phytoremediation of mercury and arsenic from tropical opencast coalmine effluent through naturally occurring aquatic macrophytes. Water Air Soil Pollut., 192: 303-314.

27. Mokhtar, H., Morad, N. and Ahmad Fizri, F.F. (2011): Hyperaccumulation of copper by two species of aquatic plants. Paper presented at: 8th IPCBEE International Conference on Environment Science and Engineering, IACSIT Press, Singapore.

28. Munagapati, V.S., Yarramuthi, V., Nadavala, S.K., Alla, S.R. and Abburi, K. (2010): Biosorption of Cu (II), Cd (II) and $\mathrm{Pb}$ (II) by Acacia leucocephala bark powder: kinetics, equilibrium and thermodynamics. Chem. Eng. J., 157: $357-365$.

29. Muramoto, S. and Oki, Y. (1983): Removal of some heavy metals from polluted water by water hyacinth (Eichhornia crassipes). Bull. Environ. Contam. Toxicol., 30: 170-177.

30. Namasivayam, C. and Periasamy, K. (1993) Water Res., 27: 1663.

31. Priya, E.S. and Selvan, P.S. (2014): Water hyacinth (Eichhornia crassipes)-An efficient and economic adsorbent for textile effluent treatment-a review. Arab. J. Chem.

32. Pulido, L.L., Hata, T., Imamura, Y., Ishihara, S. and Hajimoto, T. (1998) J. Wood Sci., 44: 237.

33. Rahman, M.A. and Hasegawa, H. (2011): Aquatic arsenic: phytoremediation using floating macrophytes. Chemosphere, 83(5): 633-646. 
34. Reddy, D.H.K., Lee, S. and Seshaiah, K. (2012): Removal of Cd(II) and Cu(II) from Aqueous Solution by Agro Biomass: Equilibrium, Kinetic and Thermodynamic Studies. Environmental Engineering Research, 17(3): 125132.

35. Rezania, S., Ponraj, M., Din, M.F.M., Songip, A.R., Sairan, F.M. and Chelliapan, S. (2015a): The diverse applications of water hyacinth with main focus on sustainable energy and production for new era: an overview. Renew. Sustain. Energy Rev., 41: 943-954.

36. Rezania, S., Ponraj, M., Talaiekhozani, A., Mohamad, S.E., Din, M.M.F., Taib, S.M., Sabbagh, F. and Sairan, F.M. (2015b): Perspectives of phytoremediation using water hyacinth for removal of heavy metals, organic and inorganic pollutants in wastewater. J. Environ. Manag., 163: 125-133.

37. Samuel, E.A., Kigho, M.O., Ganiyu, K.L. and Chiedu, N.O. (2018): Biotreatment of petroleum refinery wastewater in vertical surface-flow constructed wetland vegetated with Eichhorniacrassipes: lab-scale experimental and kinetic modelling. Environmental Technology.

38. Schneider, I.A.H., Rubio, J., Misra, M. and Smith, R.W. (1995): Eichhornia crassipes as biosorbent for heavy metal ions. Min. Eng., 8: 979-988.

39. Shabana, Y.M. and Mohamed, Z.A. (2005): Integrated control of water hyacinth with a mycoherbicide and a phenylpropanoid pathway inhibitor. Biocontrol. Sci. Technol., 15: 659-669.

40. Shen, Y., Zhua, W., Li, H., Ho, S-H., Chen, J., Xie, Y. Shi, X. (2018): Enhancing cadmium bioremediation by a complex of water-hyacinth derived pellets immobilized with Chlorella sp. Bioresource Technology, 257: 157163.

41. Shi, L., Wang, L., Zhang, T., Li, J., Huang, X., Cai, J., Lü, J. and Wang, Y. (2017): Reducing the bioavailability and leaching potential of lead in contaminated water hyacinth biomass by phosphate-assisted pyrolysis. Bioresource Technology, 241: 908-914.

42. Suflet, D.M., Chitanu, G.C. and Pora, V.I. (2006): Phosphorylation of polysaccharides: New results on synthesis and characterization of phosphorylated cellulose. Reactive and Functional Polymers, 66: 1240-1249.

43. Villamagna, A. and Murphy, B.R. (2016): Ecological and socio-economic impacts of invasive water hyacinth (Eichhornia crassipes): a review. Freshw Biol., 55(2): 282-298.

44. Wang, Q., Cui, Y. and Dong, Y. (2002): Phytoremediation of polluted waters potentials and prospects of wetland plants. Acta Biotechnol., 22(1): 199-208.

45. Wang, L.K., Vaccari, D.A., Li, Y. and Shammas, N.K. (2004): Chemical precipitation. In: Wang, LK, Hung, YT and Shammas, NK (eds.) Physicochemical Treatment Processes. Humana Press, New Jersey, 3, pp. 141-198.

46. Xiaomei, L., Kruatrachue, M., Pokethitiyook, P. and Homyok, K. (2004): Removal of cadmium and zinc by water hyacinth (Eichhornia crassipes). Sci. Asia, 30: 93-103.

47. Xu, Y., Liu, Y., Liu, S., Tan, X., Zeng, G., Zeng, W., Ding, Y., Cao, W. and Zheng, B. (2016): Enhanced adsorption of methylene blue by citric acid modification of biochar derived from water hyacinth (Eichhornia crassipes). Environ. Sci. Pollut. Res. Int., 23: 23606-23618.

48. Yu, J., Jiang, C., Guan, Q., Ning, P., Gu, J., Chen, Q., Zhang, J. and Miao, R. (2018): Enhanced removal of $\mathrm{Cr}$ (VI) from aqueous solution by supported $\mathrm{ZnO}$ nanoparticles on biochar derived from waste water hyacinth. Chemosphere, 195: 632-640.

49. Yuvaraja, G., Krishnaiah, N., Subbaiah, M.V. and Krishnaiah A. (2014): Biosorption of Pb(II) from aqueous solution by Solanum melongena leaf powder as a low-cost biosorbent prepared from agricultural waste Colloids Surf. B, 114: 75-81.

50. Zhang, F., Wang, X., Xionghui, J. and Ma, L. (2016): Efficient arsenate removal by magnetite-modified water hyacinth biochar. Environ. Pollut., 216: 575-583.

51. Zhang, F., Wang, X., Yin, D., Peng, B., Tan, C., Liu, Y., Tan, X. and Wu, S. (2015): Efficiency and mechanisms of $\mathrm{Cd}$ removal from aqueous solution by biochar derived from water hyacinth (Eichhornia crassipes). J. Environ. Manag., 153: 68-73.

52. Zhang, Q., Achal, V., Xu, Y. and Xiang, W-N. (2014): Aquaculture wastewater quality improvement by water spinach (Ipomoea aquatica Forsskal) floating bed and ecological benefit assessment in ecological agriculture district. Aquac. Eng., 60: 48-55.

53. Zheng, J.C., Feng, H.M., Lam, M.H., Lam, P.K., Ding, Y.W. and Yu, H.Q. (2009): Removal of Cu(II) in aqueous media by biosorption using water hyacinth roots as a biosorbent material. Journal of Hazardous Materials, 171: 780-785.

54. Zhu, N., Yan, T., Qiao, J. and Cao, H. (2016): Adsorption of arsenic, phosphorus and chromium by bismuth impregnated biochar: adsorption mechanism and depleted adsorbent utilization. Chemosphere, 164: 32-40. 